\title{
Negotiating Boundaries between Us and Them
}

\author{
Ethnic Norwegians and Norwegian Muslims Speak out \\ about the 'Next Door Neighbour Terrorist' in 24
}

\author{
Rolf Halse
}

\begin{abstract}
Interpretive communities can read a media text in different ways. The present article examines how various interpretive communities of young adults in Norway perceive the action serial 24 's portrayal of a Muslim family. It investigates the understandings and attitudes informants express in their conversations about the Muslim 'next door neighbour terrorist' stereotype, and sheds light on how 24's text can mobilize stereotypes and facilitate stereotyping among viewers. The findings reveal different patterns of reception. The ethnic Norwegian participants found gratifications in 24's storyline, while a majority of the Norwegian Muslims found it unpleasant and offensive. An important contribution to the fear that the stereotype evoked in the ethnic Norwegians was related to the challenge and tension it created in the negotiation process of categorization. The category 'Muslim' triggered a powerful response, and the conversation veered off in a xenophobic direction. This is an example of how an interpretive community modified its perception of the stereotype through socially patterned readings.
\end{abstract}

Keywords: audience research, stereotyping, empirical analysis, TV serial drama, focus group interviews, TV reception

\section{Introduction}

Muslims have often been portrayed as negative stereotypes in Hollywood's TV entertainment (Shaheen 2000; Woll \& Miller 1987). The traditional Muslim stereotype is usually located in a Hollywood 'Middle East', and its image is easily recognizable through a number of recurring visual elements. This image of Muslim Arabs as depicted on US TV is described by "The Instant TV Arab Kit", and consists of a belly dancer's dress, a turban, a veil, sunglasses, flowing dresses and robes, oil wells, limousines and/or camels (Shaheen 1984: 4-5). A new, threatening Muslim stereotype was identified in the 200203 US TV season by Jack G. Shaheen (2008): the Muslim Arab-American Neighbour as Terrorist. Since then, Shaheen has documented over 50 programmes featuring this stereotype. The action serial 24 has made an important contribution to promoting this new stereotype. Over several seasons, Muslim terrorists have plotted and carried out brutal attacks against the US, operating through terrorist cells. The 'sleeper cells' consist of Muslims living seemingly ordinary lives in the US, mixing in with their neighbour- 
hood. The ambiguity of these characters when introduced on screen has contributed to evoking fear and has complicated decoding, as viewers' struggle with identifying the characters' backgrounds. The main focus of the present study is on shedding light on the decoding processes of actual viewers in regard to this new Muslim stereotype.

A textual analysis of 24's representation of a Muslim family uncovered that the Muslim American 'next door neighbour' terrorist seems to resemble the appearance of the average American; on the outside, it differs from the traditional stereotype, but within, as regards its character, it remains true to type (Halse 2009). The following article presents a reception study of 24's storyline about a Muslim family, examining how various interpretive communities of young adults in Norway perceive the stereotype presented in 24's text. It investigates the kinds of understandings and attitudes informants express after having watched 24 , and studies how 24's text can mobilize stereotypes and facilitate stereotyping among viewers. This is achieved by identifying and 'tapping' the range and variety of attitudes and understandings through focus group interviews. Do the various interpretive communities read the text differently? And if so, how do their readings differ?

\section{Critical Reaction to 24}

24 has become a huge success among television audiences worldwide, ${ }^{1}$ including Norway, where it has been aired in prime time on the commercial public service channel, TV2. 24 has been a great commercial success for the channel, and when seasons 1 and 2 were aired in 2002-2003, the serial had 571000 viewers per episode, or almost half of the audience in Norway who were watching TV at that time of the day ( $V G$ 2003).

24 has aroused negative comments among media critics and scholars, especially allegations of the programme supporting US neo-conservative right wing arguments for American soldiers' use of torture during interrogation of both terrorists and suspected terrorists (Mayer 2007; Poniewozik 2007; Prince 2009). Of all of 24's seasons, season 4 has generated the largest amount of negative coverage in the US. This season faced harsh criticism from various sources, and for the first time, 24 was widely accused by Muslims interest groups of stereotyping Muslims (e.g., CAIR Chicago 2005). Fox Network TV promoted the season with the slogan 'They could be next door', together with an image of an American Muslim family. This family featured as a terror cell living in Los Angeles, and the storyline upset Muslims throughout the US (Dilullo 2007: 17). ${ }^{2}$ Fox Television took action in the US to counter the criticism and aired several public announcements in which viewers were urged not to stereotype Muslims (BBC News 2007). ${ }^{3}$ Responding to criticism of the fourth season, co-creator Joel Surnow explained: "For it to have any believability and resonance, we had to deal with the world we're living with, with the terrorists and jihadists" (Ackerman 2005). In Norway, however, the debate about 24's representation of Muslims has been ignored by the press despite the show's huge popularity.

\section{Stereotyping: An Approach to Researching TV Audiences}

Stereotypes are often used to characterize and group certain kinds of people. They serve a categorizing function - a fact first recognized by Walter Lippmann (1922), who coined this as stereotyping. Stereotyping describes a psychological mechanism that creates 
categories and enables people to better manage the swirl of data. This is a necessary and efficient process, because "the attempt to see all things freshly and in detail, rather than as types and generalities, is exhausting, and among busy affairs practically out of the question (Lippmann 1922/1991: 88). According to Lippmann, the existence and utilization of stereotypes can also be explained and understood in terms of domineering forces' need to create and sustain structures of difference and power. Both dimensions of the concept are drawn upon in the reception study reported here. The stereotype is applied as an analytical tool that can shed light on how different interpretative communities perceive 24's text.

Stereotypes have strength in that they seem to be rigid and resistant to change. At the same time, they appear to be fluid, flexible and accommodating with the social context, as the new Muslim stereotype exemplifies. Drawing on Lippmann's second explanation of the term, media research has tended to operate with the classical view of stereotypes as rigid, simplistic, overgeneralized, and erroneous (Pickering 1995: 691). This is a misleading view, which T.E. Perkins (1979) is at odds with. She argues that stereotypes are both simple and complex, as they implicate knowledge about a complex social structure. ${ }^{4}$

In social psychology, a stereotype is usually understood as a cognitive schema, and is thus conceptualized along the lines of Lippmann's first explanation. ${ }^{5}$ When social psychologists turn to examine communication phenomena, it is often to address what they see as social problems. Thus, communication processes as causes or reflections of prejudice and stereotypes have received considerable attention. Sonia Livingstone (1998: 6) argues that TV serial drama provides more complex and naturalistic texts for social perception, attribution and stereotyping research than do the artificial scenarios often used by social psychologists. TV serial texts are regarded as rich stimuli grounded in a textured social environment. The chief advantage of a qualitative approach is its ecological validity and finding a sample that reflects the population. TV serials can provide information about minority groups with which the majority has little contact, and they offer images and frameworks for day-to-day understanding, through which people subsequently interpret other social texts.

Stereotyping is an instantiation of the categorization process. It is impossible to have an impression of a group unless the difference between that group and some other group is recognized. Social identity derives from group membership (Mead 1934), and in social psychology, one theory of social identity (Tajfel, Turner 1986) indicates that social-identity processes may have implications for intergroup behaviour. This can happen if we assume that, by and large, people prefer to have a positive self-concept rather than a negative one. Social identity theory argues that, through the cognitive processes of categorization and grouping, the ingroup members will develop a stereotypical view of the outgroup members, and through the motivational process of seeking to maintain a relatively high social identity, the stereotype of the outgroup members will tend to be negative (Hinton 2000: 114-115).

\section{Towards a Multidimensional Model of TV Reception}

A basic premise for a reception analysis is that members of the audience are active readers of media messages. Therefore, the question is not only how the content influences the receiver, but also what meanings the receiver brings to the content. In his seminal 
work, the Nationwide Audience, David Morley (1980) investigates how viewers with different backgrounds interpreted the British current affairs programme Nationwide, using Stuart Hall's 'encoding/decoding' approach in the analysis of reception interviews. ${ }^{6}$ This research design resembles Morley's in that it gathers empirical data from actual viewers with different backgrounds, but applies instead Kim Schrøder's (2000, 2003) 'multidimensional model of mass media reception'. Empirical audience research has revealed that actual readings are often more complex than Hall's model is able to reveal (see Condit 1989; Barker 1998). Applying Hall's model in reception studies has resulted in research that has been too narrowly occupied with ideology and class struggle, tending to neglect other important categories, like ethnicity and culture - categories that are relevant to the present study. The multidimensional model deals more profoundly with the complexity of actualized readings to audiences. It ensures that each dimension of media reception receives analytical attention in its own right (Schrøder 2000: 254), which is important for providing an answer to the study's hypothesis.

The multidimensional model proposes to separate readers' subjectively experienced agreement or disagreement with the text from the researcher's evaluation of the role played by audiences' positions in hegemonic struggles. It is used as an analytical tool and checklist to sharpen the focus on the fundamental aspects of mediated production of meaning, and it is limited to the reception process. The model offers a theoretical framework of what is essential to investigate when it comes to media reception and includes five general and fundamental dimensions of reception. The motivation aspect highlights the relevance relation that exists between texts and their readers; comprehension deals with how audience members comprehend media content, denotatively and connotatively; discrimination is concerned with whether audience readings are characterized by an awareness of the text's 'constructedness'; position is about the 'subjective' attitude towards the text accompanying a reading and action deals with how recipients use media content in their everyday life (Schrøder 2000, 2003). ${ }^{7}$ The model makes it possible to draw attention to the heterogeneous aspects of audience discourses about media experiences and affords an opportunity to incorporate themes that follow the concrete object of an investigation.

\section{Methodological Design}

The focus group interview is a method in which several people discuss an issue with a researcher who serves as a leader/moderator. It can be used to observe how an audience creates meaning from media through conversation and interaction with each other. Its strength is that it offers "ways of eliciting, stimulating, and elaborating audience interpretations" (Hansen et al. 1998: 258). The research design has a comparative approach, as it intends to map out the reception of a TV drama among various groups of young adults in Norway. The focus group interview is known for its ability to 'tap' into human tendencies (Krueger et al. 1994: 10). Thus it suits the purpose of the present study, because attitudes, perceptions and meanings are seldom formed in a social vacuum; they are formed through interaction with other people. ${ }^{8}$ One problem with focus group interviews is when someone in the group dominates the conversation, which entails the risk of distorting the audience data, especially when this person has extreme or unrepresentative views. 
Seven focus group interviews were carried out, and the groups consisted of young adults recruited from a secondary school (five groups) and an immigrant education centre (two groups) in Norway. Each focus group consisted of three to seven informants. Both genders participated in each interview, except in one case where the group consisted of three males. Selected scenes from the serial in which the Muslim family was depicted were screened for the group. The scenes encompassed the overall storyline concerning a Muslim family in $24 .{ }^{9}$ Afterwards, the participants took part in semi-structured interviews, where the questions were related to central themes and concepts, such as the informants' perception of the characters depicted. Before screening, the interviewees were informed that the purpose of the study is to try to understand how various educational milieus interpret a contemporary US TV drama. It was stressed that nothing the informants' might say during discussions would be wrong, as long as they together discussed the moderator's questions in a thorough and honest way. ${ }^{10}$

Informants from secondary school were recruited from classes belonging to two educational programmes: Media and Communication - 'MC' (three classes) and Engineering and Industrial Production - 'EIP' (two classes). Altogether 28 informants, age 16 to 18 , participated from this school. There were six boys and six girls in the EIP focus groups, and six boys and ten girls in the MC focus groups. ${ }^{11}$ The Norwegian Muslim immigrants had been screened in advance by language teachers at the Immigrant Education Centre - 'IC'. All had lived in Norway for several years and had sufficient mastery of the language in use to participate in a research interview. These participants were practicing Muslims; all of them also came from conflict zones with predominantly Muslim populations (Palestine, Iraq, the Russian Republic of Chechnya and Somalia). ${ }^{12}$

All the focus groups were formed on the basis of pre-existing social groups. They were part of educational milieus in which they knew each other. This allowed for a permissive and familiar atmosphere. It was not a criterion to be a regular viewer of 24 . The goal was to study regular audiences' reception of a TV drama in Norway which was mass-mediated at the time. However, students who had prior experience of 24 were prioritized. Discussions, which lasted about 30-60 minutes, were recorded and transcribed. 'Nicknames' were used to ensure the participants' anonymity. The age of the informants who participated was between 16 and 29 years, which covers a good part of 24's target audience: 18-34 years (Seidman 2009). This was the main motive for selecting 'young adult' informants. ${ }^{13}$

\section{The Muslim-American Neighbour as Terrorist Plotline in Season 4}

Muslims feature as radical Islamic terrorists in five out of the total of eight seasons of 24 . Here, they typically pose the initial threat by carrying out the first, spectacular and 'shocking' attack, but are later in the season replaced by more 'resourceful' terrorists with other backgrounds. ${ }^{14}$ Habib Marwan is the enemy mastermind in season 4 . He organizes a large network of terrorists, who are mainly recruited from the Middle East, but living in the US as so-called sleeper cells.

The Araz family - husband (Navi), wife (Dina) and their seventeen-year-old son Behrooz - is one of the sleeper cells, and plays a key role in Marwan's master plan to cause numerous nuclear power stations in the US to melt down. They facilitate the acts of other terrorists mainly by delivering weapon parts and information to them. The family 
is introduced when they are having breakfast in their middleclass home, as a newscast reports on a terrorist attack they were involved in. As well as discussing the attack with his family, Navi reveals that he is aware of his son's ongoing relationship with a white American girl, Debbie, despite his disapproval of it.

During the storyline Dina kills Debbie, Navi tries to have his son killed by a fellow terrorist whom Behrooz himself kills. Navi also murders his brother-in-law and finally Behrooz commits patricide. All of this happens as the family members in turn betray each other, and eventually Navi ends up dead and the others are captured by the hero in the series, Jack Bauer.

\section{The Viewers' Relation to 24 and Popular Culture}

The motivational dimension concerns the relevance relation that exists between the readers' personal universe and the universe apprehended to be presented by the text (Schrøder 2000: 45). The majority of informants were not regular viewers of 24, and were probably not as motivated to watch it as fans would be. Of the ethnic Norwegian informants, 17 out of 28 had watched the show before; 9 of those were boys and 8 were girls. ${ }^{15}$ Most of the boys who had watched 24 reported that they had watched at least half a season, while the majority of the females had seen some episodes at random. Of the Norwegian Muslims, five had watched it, three had not and two did not answer. Most of those who had seen it before had watched only a few episodes randomly. ${ }^{16}$

The ethnic Norwegians expressed that their main reason for liking the show was the high level of excitement it offered. The Norwegian Muslim participants' discussion, however, revealed less excitement concerning its entertainment value. Some of these participants expressed ambiguity in their motivation for watching, which gave an impression of ambivalence towards what they got out of engaging with 24's text:

Moderator: What do you think about 24?

Diana (Female, IC): I think it's completely sick. This doesn't happen to ordinary people. This is nonsense.

Moderator: Do you like it then, the nonsense?

Diana: Yeah, we all watch. We all like movies.

Comprehension refers to how audience members make sense of the media content. It is examined to determine to what degree an interpretation is consistent with or aberrant from the majority of the participants' or the encoders' preferred meaning. Most of the informants seemed to be in agreement as to the text's basic storyline. On occasion participants would misread it denotatively, but when that happened, other participants would be quick to correct them. It seldom happened that the entire group was off track. The EIP community delivered more aberrant readings on a denotative level than did the MCs. A few times, the entire group gave erroneous interpretations. This happened when misreadings went unchallenged.

Moderator: What do you find interesting about the Araz family?

Hårek (Male, EIP): How that little boy tried to manage to survive and that he had the courage to stand up to his dad. He was pissed off.

Rusland (Female, EIP): The son wasn't like them. His mother was in with it [the terrorist activities] at first, when she forced her son to shoot her [Debbie]. 
Pita (Female, EIP): The mother gets her son to shoot people, different kinds of people.

'Rusland' claims that the son was forced to shoot his girlfriend, and 'Pita' supports this by adding that he was forced by his mother to kill others as well. None of this actually happened. In a MC group, an identical claim was made about the son killing his girlfriend, but this interpretation was immediately challenged by others. Here we see the kind of "relative unity amidst diversity" that an interpretive community ensures (Fish 1980). In a reception analysis, this manifests itself as socially patterned readings. The fact that the EIP community undertook more aberrant readings of the text than the MC community did may have to do with the fact that the MCs received training in decoding media texts as part of their educational programme.

For the most part, the Norwegian Muslims' discussions did not go into details concerning the actual content of the text, as the readings were primarily on a meta-level. Some seemed unfamiliar with this kind of intense and information-dense TV entertainment. The Norwegian Muslims were older than the MC and EIPs, which may give them an advantage concerning comprehension. Still, it is unlikely that they have had the same amount of exposure to US popular culture, and this was reflected in their readings, especially in their lack of references to other TV serials and films. In the questionnaire, Muslim informants reported that their favourite TV series were shows like $O$ Clone, a Brazilian soap opera, and Alzer Salem. Still, over half of the TV series reported were from the US - like Desperate Housewives and That 70's Show, indicating some familiarity with US TV series.

\section{Depiction and Perception of Religion}

When the moderator asked questions about the Muslim family's motivations, general agreement as to 'what Muslims are like' in connection with religion would often come up as logical answers for the ethnic Norwegians. ${ }^{17}$ In their readings, the majority seemed to share negative beliefs about Muslims and Islam.

Moderator: Why do you think the family is behaving in the way they do?

3 Mix (Male, EIP): It has something to do with their faith that makes them fight for the cause.

Birki (Male, EIP): The Qur'an makes people believe in this [the cause], so that they think that it's okay to kill people

Sheep (Female, MC): Actually I know people who have told me how it is in their family, and it was like you were supposed to obey the father, and if you made some mistakes you could get killed.

The violent Muslim is the most widely distributed stereotype of Muslims in Western popular culture (Karim 2003: 62). Thus, it was perhaps unsurprising that several ethnic Norwegians made generalizations about Muslims' innate tendency to kill when explaining the family's motivation. For 'Sheep', however, a personal encounter she had with Muslims came to mind and confirmed the validity of the text she had just viewed. These Muslims told her that it is a somewhat common occurrence in their families to kill their own when the father's orders were not obeyed.

In most of the ethnic Norwegians' discussions, the term Muslim was not mentioned until the last part of the interview. When someone in the group came up with the word 
'Muslim' or 'the Qur'an' (Islam was not mentioned), the conversation would veer off in a xenophobic direction, and hostile remarks and negative attributions regarding the family and the culture they represent were more frequent. ${ }^{18}$ If mentioned, the terms functioned as labels of primary potency, triggering xenophobia and negative stereotypes among the informants. Labels of primary potency are exceedingly salient and powerful, and tend to prevent alternative classification (Allport 1954: 179). Cultural/religious and racial labels, like 'Muslims' and Arabs', are often of this type, because they can resemble labels that indicate some outstanding incapacity - like 'Sheep"s belief that Muslim families are dictated by irrational, brutal and despotic fathers. ${ }^{19}$

An important contribution to the fear that the new Muslim stereotype evoked in the ethnic Norwegians was related to the challenge and tension it created in the negotiation process of categorization. The informants seemed uncertain about whether the stereotype was a foreigner or a Muslim, because in terms of appearance it did not resemble the traditional Muslim stereotype.

Kork (Male, MC): [Behrooz] is one who had experienced a tough childhood down there [Middle East] in the place that we talked about (the others laugh). It comes with the culture.

Ims (Female, $M C$ ): It could be religion (other informants: yes, religion)

Dal (Female, MC): I think it has a lot to do with (interrupted)

Kork: Their upbringing

Dal: It's what kind of view they have on life

Ims: Yeah, it's like 'I will kill my child'

Pant (Female, MC): That is a rather extreme example, though.

The term Muslim had been mentioned for the first time before this extract. Now informants joined in to share their prejudiced beliefs and perceptions of the outgroup 'Muslims', generalizing from a single instance to the group level. The conversation changed to where biased and crude attributions regarding an alien culture seemed to be an accepted way of making sense of the family's actions. They were considered as insane, primitive killers, and the explanation was found in their religion. This extract illustrates how the direction of the conversation among a majority of the ethnic Norwegian focus groups changed because of a label of primary potency, which enabled socially patterned readings and modified the perception of the new Muslim stereotype. ${ }^{20}$ But in this example, 'Pant' entered the conversation and negotiated the group assessment. In the MC community, a group member would randomly enter the negotiation process and challenge inferences made about Muslims.

A majority of the Norwegian Muslims expressed resentment and anger over 24's representation of the Muslim family. Several of them said that they feared that it might have repercussions for Muslims both in Norway and in the US, and most considered it a malicious portrayal of Muslims.

Skipper (Male, IC): As a Muslim I can't accept it, this kind of narration. It's unacceptable, because as a Muslim I have my opinions on all other fields, and if I claim and every Muslim in this world claims they are Muslims, they must have strong opinions on everything, like other human beings. You have to take responsibility for this position.

'Skipper' stressed that everyone had to stand up for who they are, including Muslims. Being a Muslim involves having responsibilities to the Muslim people, their tradition 
and to the obligations of Islam. His statement "like other human beings" indicated an attempt to assimilate Muslims into the larger group of "humans". This can be considered an effort to reduce the diverging mechanisms that stereotyping facilitates. Moreover, 'Skipper' asserted that finding enjoyment in 24's storyline cannot be combined with being a practicing Muslim. Several IC informants did not find the portrayal of Islam reliable, because they could not see any evidence that the family was motivated by jihad. And as one female informant pointed out: "Muslims need a reason to do this".

\section{Negotiating Boundaries between Ingroups and Outgroups}

Group identification is central to media audiences' selection and cognitive processing of messages, and gratifications based on group identification account for significant unique variance in TV viewing (Harwood \& Abhik 2005: 194-195). When viewers' read information about TV serial characters the cognitive process of categorization emphasizes the differences between the groups they are associated with. Thus, one can view outgroup members as more different then they actually are.

Nansi (Female, EIP): The family is totally psycho, completely whacked in their heads.

Hårek (Male, EIP): They are just ordinary Muslims

In this case, 'Nansi' described negative character traits that she ascribed to the specific family portrayed. The stereotyping started with 'Hårek's comment when he labelled the characters as Muslims and ascribed the negative traits to Muslims in general - as typical qualities. In this way, the focus group accentuated the difference between the ingroup and the outgroup by derogating the other group, where the differences within the group 'Muslims' were underestimated: they are all the same. This stereotypical reading can be seen as motivated by the group's wish to attain gratifications from intergroup comparisons, such that the group they belong to is assessed more positively.

One source of stereotyping stems from the differentiation of 'us' and 'them'. Linguistically, the division is particularly evident in the use of pronouns associated with these groups. The first person plurals (we, us) reflect a sense of ingroup cohesion, belongingness and positive evaluation, while the third person plural (they, them) tends to become associated with the opposite (Ruscher 2001: 36). 24's storyline about the Muslim family seemed to enable viewers to make this separation without effort.

Børdy (Male, EIP): They come to a new country and think that they can do things like they do back home. Grizzly (Male, EIP): Ruining it for everybody, that's what they are all about.

Børdy: Just because they feel bad about themselves.

In the interviews the family (and Muslims or 'the foreigners') was mostly referred to using the third person plural 'they' by the ethnic Norwegians. A negative evaluation would often follow, as the above excerpt shows. This linguistic pattern presented the family as a certain type of human being with major faults - as people who are unable to adapt to the culture of the ingroup because 'they' aren't like 'us'. An interesting finding concerning this pattern is that 'us' included Americans in general in 24, who were depicted as heroes and more ordinary US citizens. 'They' belonged to the outgroup, indicating that 'they' did not belong in the Western world even while living in it. The Orientalist stereotype 
of Muslims' subterfuge and deceit was drawn upon when evaluating 'them' and their participation in 'our' country/part of the world (Pickering 2001: 167).

Pant (Female, $M C)$ : A forced marriage?

Dal (Female, MC): Yeah (laughs), that's it. With him [the father], they have a nice house and a good life, sort of. Love and stuff.

Ims (Female, MC): That probably exists in those kinds of countries as well.

Dal: No, it doesn't!

Obama (Male, MC): It's like having to choose between a banana and an orange, when all you really want is an apple (group-laughter).

In the extract above, the Muslims' family life and a forced marriage were evaluated, and the understandings that were reached evoked laughter and amusement. 'Dal' used irony to ridicule the parents' relationship. 'Ims' acknowledged that they probably had love in these countries as well, but 'Dal' then rejects this in a serious tone. The stereotypical beliefs held about Muslims in general were reflected in the ironic and derogatory language used, and the intended meaning was the opposite. The example above was one of numerous cases where ethnic Norwegians utilized ingroup jokes, irony and humour, which evoked laughter when commenting on and interpreting what they believed to be the family's background, culture, and way of life. But in a few cases someone became uncertain as to how they would be perceived by the moderator when they made stereotypical attributions:

Dovendyret (Male, $M C$ ): Many foreigners think that America is guilty of all things sleazy, and they will therefore do everything in their power to ruin things for them. But we might get reported to the police if we come up with even the slightest racist remarks.

Moderator: U-huh

Trollet (Female, MC): Was that a yes?

'Dovendyret' addressed the topic of retaliation: autochthonous people dare not complain openly for fear of revenge by the overall norm of tolerance or by victims of such talk (see van Dijk 1987: 146-148). Then, 'Trollet' tried to ground the conversation, probably seeking confirmation of a shared view on foreigners on the part of the moderator in order to solicit shared understandings. Such a view could not be solicited, because the moderator's task is to stay as neutral as possible in a focus group interview.

Most of the IC community seemed on occasion to share in their readings prejudiced beliefs about and bias towards the people they held responsible for the text: 'the Americans'.

Mady (Female, IC): I think that when the Americans started to make such movies, they are teaching people to become like this. Everyone watches, and then at the same time they started with terrorism as well, in different countries.

AF (Male, IC): They teach children how to work.

Mady: Yes, they teach children, because children also play the same game when they watch this type of film. They're the ones who learn to become crazy.

Stereotypical statements like "everyone watches" and then "become crazy" reflected homogeneous perceptions of Americans. The outgroup bias the IC community exhibited had similarities with the ethnic Norwegians' stereotyping of Muslims, including 
an identical linguistic pattern following the use of 'they'. The perceptions are related to James G. Carrier's (1995) notion of Occidentalism. One type of Occidentalism occurs "In studies of the ways that people outside the West imagine themselves, for their selfimage often develops in contrast to their stylized image of the West" - they define the West in an essential manner" (Carrier 1995: 6). However, the IC community used the term Americans, a more specific label, indicating that the informants did not include other Western countries in the outgroup. During the conversations the term Americans was often applied as if it represented some type of unified entity with a shared view and values. The community defined Americans in contrast to how they would define themselves - a reading strategy that seeks gratification through group identification by contrasting 'our' values with the negative values of the outgroup. In the extract, the outgroup was depicted as consisting of amoral, insensitive, manipulated cultural dupes.

Among the Muslim immigrants, there were also a few who disagreed with the majority's readings. For instance, one informant claimed that in reality a Muslim family can have the sort of problems that the serial addressed. He considered the representation of the family to have a kernel of truth, claiming that a family from Afghanistan he knew about had to face identical problems.

\section{Position and Action}

The notion position covers the informants' subjective experience of agreeing or disagreeing with the perspective perceived to exist in the text. In the analysis of the transcripts three types of readings were found. The categories were defined according to informants' attitudes towards 24's text, and were labelled as sympathetic, sceptical and dissident. ${ }^{21}$ Examples of all three types of readings were found in the interview data. The analysis shows that the EIP community's readings were sympathetic to 24's story. For the most part, the informants talked about the text as something they could easily assess and grasp the intended meaning of. Sympathetic readings were seen in utterances where informants aimed to discover, in as loyal a manner as possible, what might be assumed to be the original intention of the producer of the text (Gripsrud 2002: 142), or where the text was viewed as more or less representing 'reality'.

Moderator: What did you find interesting about the Araz-family?

Birki (Male, EIP): The way they persuaded that little boy to kill her [Debbie], and the crazy stuff they made him do. They got him to cover it up by making him show his mobile phone, for example. There were things there preceding it; if he didn't obey he would die.

'Birki's' interpretation was typical for the EIP community; most readings suggested that viewers sided with and identified with the boy, considering him a 'normal' teenager innocently caught up in a hostile family and culture. As one informant put it: "he didn't do anything wrong". There was no indication in the viewers' utterances of a sceptical attitude towards the content. The readings correlated with how the producers of 24 claimed they portrayed the family. Executive producer and director of 24, Jon Cassar boasted that they are good at fleshing out bad guys and basing them in reality, and that they were especially successful with the Muslim family (Dilullo 2007: 90).

Most informants in the MC community had a sympathetic view on 24's portrayal and displayed a positive and affectionate attitude towards the text. Like the EIP community, 
they identified with Behrooz and the problems he had to face. In the readings of the parents, they expressed negative views on their behaviours and culture, but seldom on 24 's representation of them. Some readings fell in the category sceptical, but these were exceptions. Sceptical readings were found in those utterances that expressed doubt about 24's depiction of social, political or cultural aspects.

The majority of the Norwegian Muslim community could readily be described as dissident readers. In the dissident readings, the intended meaning of the text was seemingly comprehended, but vigorously opposed and rejected. The way characters were portrayed evoked anger and resentment. Some informants refused to explain what they disliked, and a male informant simply dismissed it as "a stupid story". For him it was a waste of energy to elaborate on what he had seen. A salient feature in the readings was how this would be perceived by people in Western countries, especially Americans. A female informant was for instance worried that Americans would consider this family to be typical of Muslim families in general. Most of the informants rejected the text's position and content, and couldn't identify with the characters or accept the storyline. Still, a minority expressed a more positive attitude towards the text.

The action dimension is narrowly understood as readings in which viewers make claims or hints about subsequent social practice. In the interview data, this occurred only in relation to dissident readings. A few Norwegian Muslims expressed readings that pointed to social practices influenced by encounters with media texts such as 24 's. One informant claimed that the limited diversity that Norwegian TV channels offered Muslims led them to watch satellite TV instead, asking rhetorically: "what else can we do if stuff like this is aired every evening?" His comment can be interpreted as a confirmation of the so-called 'media ghetto' thesis: the notion that most immigrants turn to ethnic media exclusively in order to preserve and conform their ethnic identities (cf. Bailey and Harindranath 2006). Several Muslim informants stated that entertainment like 24's text promoted discrimination against Muslims. One viewer related this to a personal experience.

Fatima (Female, IC 20): There are probably many who watch this movie who are afraid to have contact with us. Now, I am here at school and I have many friends, but they ask me such difficult questions, so I answer them what I think is right. But I have noticed that they don't make contact with other Muslims, because they think that they are so bad.

An understanding of this statement is that 'Fatima' assumes a connection between non-Muslims' reading of texts like 24's and a subsequent social practice, such as avoiding contact with Muslims. An assumed key factor in the explanation of why most Muslim informants were positioned as dissident readers was that they made this connection when interpreting the text.

\section{Concluding Remarks}

Findings identified different patterns of reception. On the one hand the ethnic Norwegian participants found gratifications in 24's storyline; on the other, a majority of the Norwegian Muslims found it unpleasant and offensive. There was a notable distinction in the readings concerning how different people were divided into groups, depending on the interpretive community's ethnic and cultural background. Most frequently the 
ethnic Norwegians would label Muslim characters in the storyline and the people they associated them with as 'the foreigners' - as an unspecified, homogeneous outgroup while most of the Muslim informants seemed to regard 'Americans', whom they held responsible for the text, as a more specific outgroup.

An important contribution to the fear that the new Muslim stereotype evoked in the ethnic Norwegians was related to the challenge and tension it created in the negotiation process of categorization. The informants seemed uncertain as to the ethnicity and status to the characters, probably because their appearance did not resemble traditional Muslim stereotypes. The IC community, however, readily identified these characters as Middle Eastern Muslims. The findings show how the ethnic Norwegian community modified their understandings of 24's text and the perception of the Muslim stereotype through socially patterned readings. Moreover, they confirmed the growing importance of ethnic and cultural identities in the viewing of US TV serials in Norway, and demonstrated the variety of interpretations found among the Norwegian young adults. They also showed that texts like 24's can function as stimuli for interpretive communities in the negotiation of boundaries between us and them.

It is plausible to argue that the new Muslim stereotype, in addition to eliciting insecurity and xenophobia amongst non-Muslims, is also troubling for the Muslim immigrant community. The bifurcated stereotype narrows their opportunity to counter the values and morals embedded in it by adapting to the societies they migrate to; because no matter how successful they are at assimilating to the Western lifestyle and appearance - on the inside they are deemed according to the old stereotype and are presumed to be secretly waiting for the right moment to destroy Western values and the Western way of life.

Serial dramas like 24 participate in forming an arena, in which representations, social identities and borders between ingroup and outgroup members are constructed and negotiated. The most important function of the stereotype is to maintain sharp boundary definitions, to define clearly where the pale ends and thus who is clearly within and who is clearly beyond it, to make visible the invisible (Dyer 2002: 16). The most troublesome aspect of the new Muslim stereotype's impact on Western TV audiences is how it enables one to make sharp boundary definitions. The vast and heterogeneous category 'Muslim' is, needless to say, insufficient for labelling potential Islamic terrorists. This study, however, documents that in the decoding process, a majority of the ethnic Norwegians would label Muslims in general as the outgroup as plausible terrorists. The new Muslim stereotype seems to facilitate a perceptual slide between cultural and ethnic categories and offer non-Muslims a bifurcated image of Muslims in day-to-day understanding. This may, in effect, have consequences for social perception in general. If steadily repeated by mass mediation, this stereotype is disquieting news for Muslim minority groups in Western societies.

Defining world events in the past three decades - like Israel's invasion of Lebanon (1982), Operation Desert Storm (1991), and the military invasions into Afghanistan and Iraq (2001 and 2003) - has made an impact on Hollywood's representation of Muslims and Arabs. Hollywood's dispatching and replacement of desert nomads and oily sheiks by the violent and crazed Islamic fundamentalist is a result of these developments (Shaheen 2008: XVI). Acts of terror against Western countries in the past decade and the following rolling news coverage - like the 9/11 attacks on the US (2001) and the Madrid and London bombings in Europe (2004 and 2005) - have 
paved the way for an alternative Muslim stereotype to encapsulate the new threat. These media events have made the Western public aware of the danger posed by Muslim 'sleeper cells', and fictitious representations of this image can thus be viewed as having a kernel of truth. The image is now at the threshold of becoming a common feature in Hollywood's TV entertainment, and further research is needed to elucidate its development and audience reception.

\section{Notes}

1. For instance, on the premiere night, season 6 of 24 had 15.7 million viewers in the US alone (Mahan 2007).

2. Christian Blauvelt (2008) claims that the plot in 24 about the Muslim family works like Nazi propaganda fiction films did, like Jud Suss (1940) and Der Ewige Jude (1940), which instilled in people the fear that their Jewish neighbours might be working to establish a foothold in Germany for the Soviet Union.

3. Executive producer and scriptwriter of 24, Howard Gordon, mentioned that he became aware of the dilemma that 'fear sells' during the promotion of season 4. Fox's marketing department was promoting the season with the slogan 'They could be next door', suggesting that this Muslim family could be anyone's neighbour. The Council on American-Islamic Relations (CAIR) was concerned that the promotion and the show might incite violence and racial hatred. Gordon stated in a panel debate concerning this issue: "we were acting as handmaids to fear" (Gumbel 2008).

4. An example of a stereotype that is not simple is the dumb blonde. Understanding this stereotype demands that one sees more than just hair colour and lack of intelligence. It refers to her sex, which refers to her status in society, her relationship to men, her inability to behave and think rationally, etc. (Perkins 1979:139)

5. In social psychology a stereotype is commonly understood as a mental schema that economizes information processing. A definition is: "a specific type of schema, which is a network of beliefs that specify characteristics describing a certain concept. A stereotype is a schema about members of a social group, whether that grouping is based on gender, ethnicity, sexual orientation, nationality, regionality, or the like" (Ruscher 2001:4).

6. Prior to Morley's audience study, he and Charlotte Brunsdon (1978) had already undertaken an encompassing textual analysis of the Nationwide programme.

7. In this study, the evaluation dimension of the model is left out, as Schrøder does in a revised version (Schrøder 2003). Moreover, and in accordance with the model's heuristic intention, the discrimination dimension is left out. Interestingly enough, the informants showed few signs of an awareness of the 'constructedness' of the text in their readings of 24.

8. Having to choose between individual interviews or focus group interviews can be difficult. The individual interview enables the researcher to yield rich material, because she can go in depth and elicit spontaneity and reflection in the interview situation (Gentikow 2005:84). This study has a comparative approach where the aim is to investigate informants' readings based on their ethnic and cultural backgrounds. The focus group interview is preferable, as it sheds light on media reception in the context of interpretative communities.

9. In 24 , four or five stories are usually told simultaneously in one episode, and there are often sharp transitions between the plots. The plot involving the family did not intersect with the other storylines in season 4 , so it could readily be extracted from the episodes it featured in. One limitation of this approach is that the larger context around these scenes was left out owing to practical concerns about carrying out focus group interviews.

10. The moderator had previously worked as a teacher at secondary school. The knowledge obtained there was an asset for making the informants feel comfortable and helping them to speak out.

11 Selecting students from different educational programmes helped avoid recruiting a homogeneous group of informants as regards social background. Students in MC aim first and foremost at qualifying for higher level studies, while students at EIP do not.

12. In total there were 10 first-generation Norwegian immigrant informants (three women and seven men), and their age varied from 20 to 29 years.

13. In Norway today the youth period in life is considered to last longer than just some decades ago. For many in their youth a new phase has emerged that comprises both the teenage years and a later phase of education, from eighteen until individuals are in their mid- to late twenties. This is understood as the 'young adult' period and is to a large degree constituted by the educational society (Frønes and Brusdal 2000:50). 
14. While seasons 2, 5, 6 and 8 focus on a more powerful non-Islamic force as the main enemy to the US, which manipulates and uses Islamic extremists as 'puppets on a string' for its own political and financial ends, Muslim terrorists are the main enemy in season 4.

15. After each interview session, participants were asked to fill out a questionnaire with questions about, among other things, their age, what they like/dislike about 24 and their favourite TV serials.

16. The story about the Muslim family can be related to the everyday life of first generation Muslim immigrants in Western countries. This probably increased the Muslim participants' motivation for watching the text.

17. During (and before) a focus group interview value-laden terms like Muslim, terrorist, and Islam were not used by the moderator. It was assumed that this could influence the informants' readings.

18. In the questionnaire the ethnic Norwegian viewers answered whether they knew a Muslim personally. In the MC community, 8 informants did and 8 did not, and in the EIP community, 7 informants did and 3 informants did not.

19. Gordon W. Allport (1954:179) writes that "labels of primary potency act like shrieking sirens, deafening us to all finer discriminations we might otherwise perceive", because they distract our attention from the concrete reality.

20. The finding supports David Morley's (1980) argument that social groups provide resources and narratives within which individuals understand the media.

21. These categories are inductively generated from the data. They correspond to some degree with the reading strategies proposed in Hall's model: dominant, negotiated and oppositional readings (Hall 1973).

\section{References}

Ackerman, S. (2005, May 16) How real is “24”?, Salon.com. Retrieved November 11, 2008 from the World Wide Web: http://dir.salon.com/story/ent/feature/2005/05/16/24/index.html

Allport, G.W. (1954) The Nature of Prejudice. MA: Addison-Wesley Publishing Company, INC.

Bailey, O.G. \& Harindranath, R. (2006) 'Ethnic Minorities and the Politics of Communication in the Multicultural Britain and Australia'. International Journal of Media and Cultural Politics 2(3): 299-316.

Barker, M. \& Brooks, K. (1998) Knowing Audiences: Judge Dredd, its Friends, Fans and Foes. Luton: University of Luton Press.

$B B C$ News (19.1.2007) 24 under fire from Muslim groups. Retrieved September 9, 2008 from the World Wide Web: http://news.bbc.co.uk/1/hi/entertainment/6280315.stm

Blauvelt, C. (2008) 'Aladdin, Al-Qaeda, and Arabs in U.S. film and TV'. A review of Jack G. Shaheen (2001) Reel Bad Arabs. How Hollywood Vilifies a People. Jump Cut 50(1).

Brunsdon, C. \& Morley, D. (1978) Everyday Television: Nationwide. London: British Film Institute.

CAIR Chicago (10.1.2005) Action Alert: Watch '24' Tonight on Fox. Retrieved November 10, 2008 from the World Wide Web: http://chicago.cair.com/actionalerts.php?file=aa_watchfox01102005

Carrier, J.G. (1995) 'Introduction', in J.G. Carrier (ed.) Occidentalism: Images of the West, Oxford: Clarendon Press.

Condit, C.M. (1989) 'The Rhetorical Limits of Polysemi'. Critical Studies in Mass Communication 6(2): $103-122$.

DiLullo, T. (2007) 24: The Official Companion. Seasons 3 \& 4. London: Titan Books.

Dyer, R. Dyer, Richard ([1993] 2002) 'The Role of Stereotypes', pp. 11-18 in R. Dyer (ed.) The Matter of Images: Essays on Representation. London \& New York: Routledge.

Frønes, I. \& Brusdal, R. (2000) På sporet av den nye tid: kulturelle varsler for en nar fremtid [Tracking the new age: Cultural warnings of a near future]. Bergen: Fagbokforlaget.

Fish, S. (1980) Is there a Text in this Class? The Authority of Interpretive Communities. Cambridge, MA: Harvard University Press.

Gentikow, B. (2005) Hvordan utforsker man medieerfaringer? Kvalitativ metode. [How does one explore media experiences? Qualitative methods]. Kristiansand: IJ-forlaget.

Gripsrud, J. (2002) Understanding Media Culture. London: Arnold.

Gumbel, A. (2008, July 1) Operation stereotype, The National Newspaper. Retrieved January 16, 2009 from the World Wide Web: http:/www.thenational.ae/article/20080701/ART/778591133 27.9.2008.TV.com

Hall, S. (1973) 'Encoding/decoding in Television Discourse', in S. Hall et al., (eds) (1981) Culture, Media, Language, London: Hutchinson.

Halse, R. (2009) 'De kan være naboene dine' - Fremstillingen av en muslimsk familie i sesong 4 av 24' ["They could be next door" - the portrayal of a Muslim family in 24, season 4]. Norsk Medietidsskrift 16(3): 231-251.

Hansen, A., Cottle, S., Negrine, R. \& Newbold, C. (1998) Mass Communication Research Methods. Basingstoke: McMillan. 
Harwood, J. \& Abhik, R. (2005) 'Social Identity Theory and Mass Communication Research', pp. 189-211 in J. Harwood \& H. Giles (eds) Intergroup Communication: Multiple Perspectives. New York, Washington, D.C./Baltimore: Peter Lang.

Hinton, P.R. (2000) Stereotypes, Cognition and Culture. East Sussex: Psychology Press.

Karim, K.H. ([2000] 2003) Islamic Peril. Media and Global Violence. Montreal/NewYork, London: Black Rose Books.

Karim, K.H. (1997) 'The Historical Resilience of Primary Stereotypes: Core Images of the Muslim Other', pp. 153-182 in S.H. Riggins (ed.) The Language and Politics of Exclusion. Others in Discourse. Thousand Oaks, London, New Delhi: Sage Publications

Krueger, R.A. \& Casey, M.A. (1994) Focus Groups: A Practical Guide for Applied Research. London: Sage Publications.

Lippmann, W. ([1922] 1991) Public Opinion. New Brunswick and London: Transaction Publishers.

Livingstone, S. ([1990] 1998) Making Sense of Television: The Psychology of Audience Interpretation. London and New York: Routledge.

Mahan, C. (2007, January 16) Ratings: Jack Bauer vs. Globes, TV.com. Retrieved June 6, 2009 from the World Wide Web: http://www.tv.com/24/show/3866/story/8132.html?tag=story_list;title;6

Mayer, J. (2007, February 19) Whatever it Takes: The Politics of the Man Behind "24.", The New Yorker. Retrieved September 17, 2008 from the World Wide Web: http://www.newyorker.com/ reporting/2007/02/19/070219fa_fact_mayer

Mead, G.B. (1934) Mind, Self and Society. Chicago: University of Chicago Press.

Morley, D. (1980) The 'Nationwide'Audience. London: British Film Institute.

Perkins, T.E. (1979) 'Rethinking Stereotypes', pp 135-159 in M. Barett (ed.) Ideology and Cultural Production. London: Croom Helm ltd.

Pickering, M. (2001) Stereotyping. The Politics of Representation. Houndmills, Basingstoke, Hampshire \& New York: Palgrave.

Pickering, M. (1995) 'The Politics and Psychology of Stereotyping'. Media, Culture \& Society. 17: 691-700.

Poniewozik, J. (2007, January 14) The Evolution of Jack Bauer, Time Magazine. Retrieved September 17, 2008 from the World Wide Web: http:/www.time.com/time/magazine/article/0,9171,1576853,00.html

Prince, S. (2009) Firestorm: American Film in the Age of Terrorism. New York: Colombia University Press.

Ruscher, J.B. (2001) Prejudiced Communication: A Social Psychological Perspective. New York, London: The Guilford Press.

Schrøder, K. (2003) 'Generelle aspekter ved mediereception? -Et bud på en multidimenional model for analyse af kvalitative receptionsinterviews' [General aspects of reception? A proposed multidimensional model for the analysis of qualitative reception interviews]. Mediekultur 35: 63-73.

Schrøder, K. (2000) 'Making Sense of Audience Discourses. Towards a Multidimensional Model of Mass Media Reception'. European Journal of Cultural Studies 3[2]: 233-258.

Seidman, R. (2009, January 13) Monday Ratings: Two and Half Men and 24 rule Monday night, TV by the Numbers. Retrieved May 19, 2009 from the World Wide Web: http://tvbythenumbers.com/2009/01/13/ monday-ratings-two-and-half-men-and-24-rule-monday-night/10695

Shaheen, J.G. (2008) Guilty: Hollywood's Verdict on Arabs After 9/11. Northampton: Olive Branch Press.

Shaheen, J.G. (2000) 'Hollywood's Muslim Arabs.' The Muslim World 90.1-2, 22-43.

Shaheen, J.G. (1984) The TV Arab. Bowling Green, Ohio: Bowling Green State University Popular Press.

Tajfel, H. \& Turner, J.C. (1986) 'The Social Identity Theory of Inter-group Behavior', pp. 7-24 in S. Worchel \& L.W. Austin (eds.) Psychology of Intergroup Relations. Chicago: Nelson-Hall.

Van Dijk, T. (1987) Communicating Racism: Ethnic Prejudice in Cognition and Conversation. Philadelphia, PA: John Benjamins.

Verdens Gang (26.11.2003) Mer "24" på TV2 i 2004 [More of "24" on TV2 in 2004]. Retrieved October 3, 2008 from the World Wide Web: http://ret-web01.int.retriever.no/services/webdocument.html?docume $\mathrm{ntId}=0023042003112603377750$ \&serviceId $=2$

Woll, A.L. \& Miller, R.M. (1987) Ethnic and Racial Images in American Film and Television: Historical Essays and Bibliography. New York: Garland. 